Swarthmore College

Works

2-1-2005

\title{
Mechanisms For The Environmental Regulation Of Gene Expression: Ecological Aspects Of Animal Development
}

\author{
Scott F. Gilbert \\ Swarthmore College, sgilber1@swarthmore.edu
}

Follow this and additional works at: https://works.swarthmore.edu/fac-biology

Part of the Biology Commons

Let us know how access to these works benefits you

\section{Recommended Citation}

Scott F. Gilbert. (2005). "Mechanisms For The Environmental Regulation Of Gene Expression: Ecological Aspects Of Animal Development". Journal Of Biosciences. Volume 30, Issue 1. 65-74. DOI: 10.1007/ BF02705151

https://works.swarthmore.edu/fac-biology/192

This work is brought to you for free by Swarthmore College Libraries' Works. It has been accepted for inclusion in Biology Faculty Works by an authorized administrator of Works. For more information, please contact myworks@swarthmore.edu. 


\title{
Mechanisms for the environmental regulation of gene expression: Ecological aspects of animal development
}

\author{
SCOTT F GILBERT \\ Department of Biology, Swarthmore College, 500 College Avenue, Swarthmore, PA 19081 USA \\ (Fax, 610328 8049; Email, sgilber1@Swarthmore.edu)
}

\begin{abstract}
The environment can play a significant role in the production of phenotypes. However, the developmental mechanisms by which the environmental agents effect normal development are just becoming known. At least three paths have been found through which the environment can modify gene activity. The first is the neuroendocrine route. Here, the nervous system monitors the environment and transfers signals to the endocrine system. The endocrine hormones can then alter gene expression. The second route involves environmental factors that change the methylation pattern of genes, thereby altering their transcriptional capabilities. The third route involves the direct induction of gene expression in the host by microbial symbionts. The normal regulation of phenotype production by the environment should be considered a normal component of development and developmental biology.
\end{abstract}

[Gilbert S F 2005 Mechanisms for the environmental regulation of gene expression: Ecological aspects of animal development; J. Biosci. 30 65-74]

\section{Introduction}

\subsection{The new awareness of ecological developmental biology}

It had long been thought that the environment played only minor roles in development. Nearly all developmental phenomena were believed to be regulated by genes and signals within the embryo, and those organisms whose development was significantly regulated by the environment were considered interesting oddities. However, recent studies have shown that the environmental context plays significant roles in the development of most all species, and that the animal genomes have evolved to respond to expected environmental conditions (Gilbert 2001; West-Eberhard 2004). Moreover, symbiotic associations, wherein the genes of one organism are regulated by products of another organism, appear to be the rule rather than the exception (see McFall-Ngai 2002; Xu and Gordon 2004). One of the reasons why developmental biologists have largely ignored the environment is that one of the criteria for selecting the animals we study has been their ability to develop regularly in the laboratory. Given adequate nutrition and temperature, these 'model systems' develop independently of their environment (Bolker 1995). These animals can give one the erroneous impression that everything needed to form the embryo is within the fertilized egg.

Today, with new concerns about the loss of organismal diversity and about the effects of environmental pollutants, there is renewed interest in the regulation of development by the environment (see van der Weele 1999; Gilbert 2001; Aitken et al 2004). It has been known since the 1960s that environmental factors such as drugs (thalidomide) or viruses (rubella) could significantly harm human fetuses. But if the environment could play a harmful role, might it not also play a beneficial, expected, and even an evolutionarily selected role in normal development? In most cases studied, the environment was thought to play only a permissive role in development. In other words, a proper environmental context needed to be present (the uterine environment, the proper temperature, $\mathrm{pH}$, etc.), but it was not thought to have instructive abilities. Indeed, the idea

Keywords. Ecological developmental biology; environmental agents; symbiosis 
that the environment may instruct phenotype production had been a politically sensitive area of embryology after Lysenko took over most of Russian biology and made that his hallmark creed (see Lindegren 1966; Gilbert and Bolker 2003). However, there were numerous cases that had already been well established where the environment of the developing animal played a major role in producing a particular phenotype (see Hertwig 1894; Schmalhausen 1949). The ecological component of developmental biology had been central to early efforts to introduce experimentation into this field (Nyhart 1995). In his 1894 volume The Biological Problem of Today: Preformation or Epigenesis?, Hertwig noted the differences between the opposing preformationist and epigenetic theories, and he suggested a compromise: "My theory may be called evolutionary (i.e. preformationist) in the sense of because it assumes the existence of a specific and highly organized initial plasm as the basis for development. It may be called epigenetic, because the rudiments grow and become elaborated, from stage to stage, only in the presence of numerous external conditions and stimuli...." (p. 136). $\mathrm{He}$ also proposed the extension of epigenesis from interactions between embryonic cells to interactions between developing organisms and their environments, citing numerous examples of developmental plasticity insect caste determination and including insect sex determination and environmentally mediated sexual dimorphism in the echiuroid worm Bonellia and certain barnacles.

Unfortunately, soon after its publication, Hertwig's reasoned perspective on the environmental context of development became eclipsed and then almost forgotten. First, the rise of Entwicklungsmechanik (developmental physiology) brought embryology indoors. The introduction of cytological techniques, as well as polemics by Roux and others, helped to shift the focus of embryology from Bildung (development according to context) to Entwicklung (the expression of pre-existing potential). Second, starting in the 1960s, the fusion of embryology with genetics formed developmental genetics, a discipline that explicitly treated phenotype as a direct 'readout' of the nuclear genome (see Gilbert 1996; Lewontin 2000).

While most of the scientific world lost interest in the environmental regulation of development, this environmentalist tradition lived on in Russia, eventually becoming a major part of the Soviet agenda for developmental biology. To A N Severtsov, one of the founders of the Russian school of evolutionary morphology, a complete theory of evolution had to causally explain the morphological changes seen in paleontology through the mechanisms of genetics, ecology and embryology. He felt that genetics alone was insufficient, because it did not address the 'how' of evolution (Adams 1980; Levit et al 2004). Only ecology and embryology, together, could provide a mechanism for evolutionary change. In his landmark volume
Factors in Evolution (1949), Severtsov's student, I I Schmalhausen, attempted to integrate evolutionary morphology, population genetics, experimental embryology, and ecology into a coherent framework to provide a causal theory for evolution. Schmalhausen emphasized what he called 'dependent morphogenesis' (i.e. that part of development which depends on its environmental context), norms of reaction, the ability of organisms to inherit such norms of reaction, and the ability of the environment to induce changes in development, all concepts that later became essential to his notion of stabilizing selection (what $\mathrm{C} \mathrm{H}$ Waddington [1953] later called 'genetic assimilation').

Severtsov's doctrines were embraced by the Lysenkoists, who in 1948 declared Severtsov's research congruent with current Soviet ideology. But these same Lysenkoists condemned his student Schmalhausen's attempt to bring such studies in line with 'Mendelian-Morganist' genetics (Adams 1980). The Lysenkoists viewed the environment as being critically important in determining phenotype, and denounced those who thought the genome was the primary cause of phenotypes. The resulting firing, exiling and murdering of geneticists and the destruction of their research contributed to the rejection of the milder Hertwig-Schmalhausen program of ecological developmental biology in the West. The adoption and exaggeration of this program by Soviet ideologues may explain why context-dependent development was not revitalized until the last years of the 20th century: the tradition of developmental biology investigating non-genomic contributions to development may have been a casualty of the Cold War (see Lindegren 1966; Lewontin and Levins 1976; Sapp 1987). If attempts to re-integrate developmental biology with evolution had to exorcise the ghost of Ernst Haeckel (Gould 1977), then attempts to re-integrate developmental biology with ecology may have to exorcise the ghost of Trofim Lysenko. Both specters represent triumphs of political ideology over scientific investigation.

In addition, neo-Darwinism linked evolution with population genetics (and not developmental genetics). To get a good genetic story, one does not want to deal with organisms whose phenotype is significantly controlled by the environment. As Sonia Sultan (2003) points out, "neoDarwinian botanists were often quite frustrated in their attempts to discern genetically based local adaptations through this "environmental noise,"' and this led them to overlook the adaptive nature of these plastic responses. In the zoological side of developmental biology, the desire to link genetics with developmental biology (and the desires to easily breed the animals) led to the adoption of a very limited number of model species, each of whom had been selected for the lack of significant environmental components to the phenotype (Bolker 1995)

However, despite its historical difficulties and unfortunate political entanglements, the tradition of ecological 
developmental biology, including the study of developmental plasticity, never entirely disappeared. Rather, its practitioners dispersed into a variety of fields, investigating larval settlement cues, diapause, nutritional polyphenisms, life history strategies, symbioses, and other topics outside the mainstream of genome-centered developmental biology.

One of the problems with the acceptance of environmental effects on phenotype production has been the reluctance to see the mechanisms whereby the immediate environmental conditions can bring about changes in phenotype. The explanation for this reluctance probably concerns the separation of our biological disciplines. To understand how environment may control phenotype, it is necessary to understand ecology and physiology as well as developmental biology. This article will argue that the environment can accomplish its specific instructional tasks during development by at least three major routes:

- Through the neuroendocrine system: In most of these cases, the nervous system monitors the environment and changes the hormone mileau within the organism. The hormones alter the gene expression patterns and regulate phenotype production.

- As an embryonic inducer: The environmental factor acts to induce the formation of paracrine factors or it can act as part of a paracrine factor complex.

- As a transcriptional modulator: The environmental factor acts upon the genome to alter the methylation status of the DNA and changes which genes are expressed.

\section{Signal transduction from environment to genome via the neuroendocrine system}

\subsection{Neural signals altering production of ecdysone in insects}

One of the first documented cases of environmental determination of phenotype came from the butterfly Araschnia levana. The butterflies eclosing in the spring are so different from the butterflies eclosing in the summer that Linnaeus classified them as two different species. The spring morph is bright orange with black spots, while the summer form is mostly black with a white band. In 1875 , August Weismann demonstrated that these butterflies were the same species, but that temperature caused the different phenotypes. By incubating the caterpillars in different conditions, he could get the spring form in the

Normal summer form
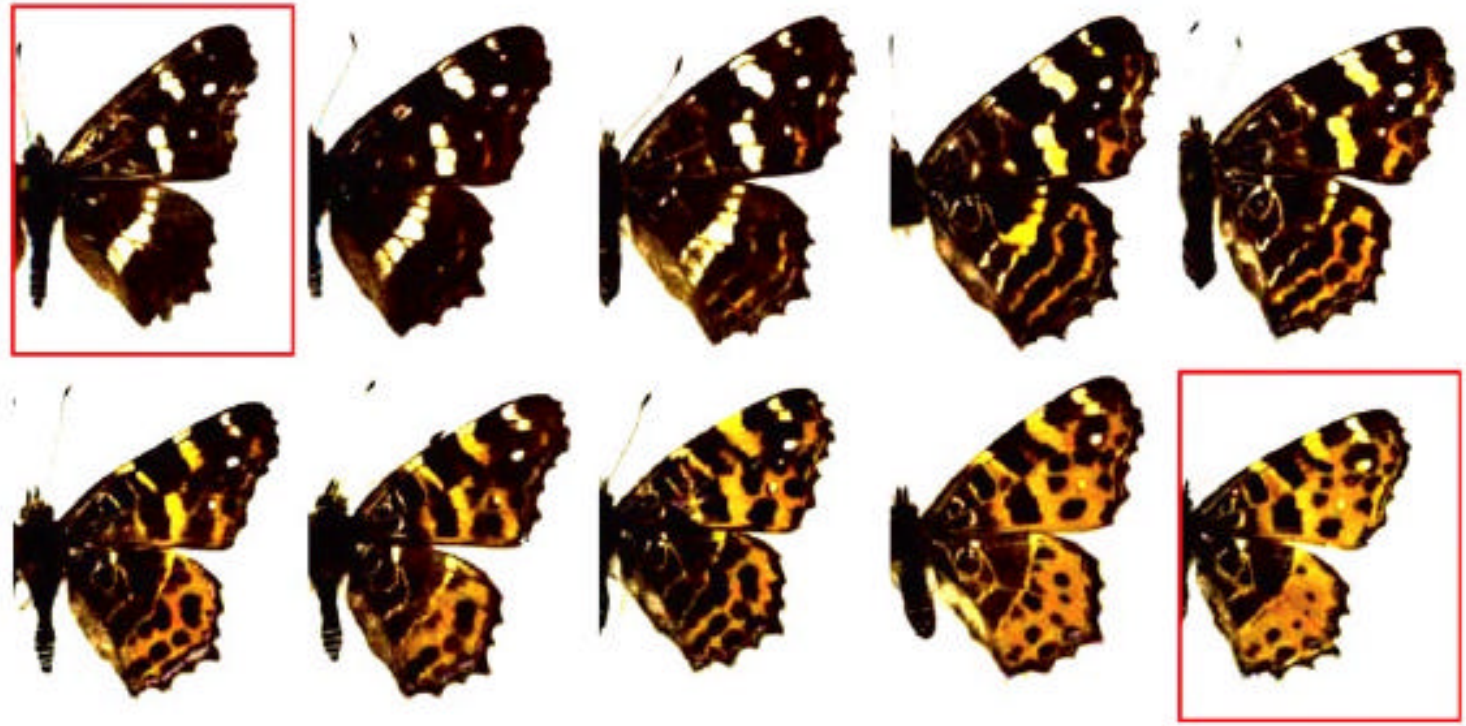

Normal spring form

Figure 1. Hormonal regulation mediates the environmentally controlled pigmentation of Araschnia. In the wild, different generations experience different temperatures and photoperiods. In the spring, there is no pulse of ecdysone during early pupation, and the orange wing pattern is generated. When these spring butterflies mate, the larvae experience longer photoperiod and higher temperatures. This induces the ecdysone pulse, and the summer (black) pigments are formed. In the laboratory, injections of ecdysone at different times during pupation can induce the intermediate phenotypes as well as others not seen in the wild. (From Nijhout 2003; photograph courtesy of H F Nijhout.) 
summer. It is now known that the normal change from spring to summer morph is controlled by changes in both day length and temperature during the larval period (Koch and Buchmann 1987; Nijhout 1991). Moreover, we now know that the temperature and daylight signals produce the phenotype by regulating the amount of the hormone ecdysone in the larva. In the spring, there is no pulse of ecdysone during this particular stage of development. In the summer there is. If one injects ecdysone into the larva during this time, the spring form can be converted to a summer form. Intermediate amounts of ecdysone can give intermediate phenotypes that are not found in natural conditions (Nijhout 2003; figure 1).

In some instances, the hormones have been shown to regulate the exression of particular genes. In Malawi, where there is a hot wet season and a cooler dry season, the butterfly Bicyclus anynana has a polyphenism that is adaptive to seasonal changes. It occurs in two phenotypes (morphs). The dry-season morph is cryptic, resembling the dead brown leaves of its habitat. The wet-season morph is more active, and it has ventral hindwing eyespots that deflect attacks from predatory birds and lizards. The determining factor appears to be the temperature during pupation. Low temperatures produce the dry-season morph; high temperatures produce the wet-season morph (Brakefield and Reitsma 1991). The development of butterfly eyespots begins in the late larval stages, when the transcription of the Distal-less gene is restricted to a small focus that will become the center of each eyespot. During the early pupal stage, Distal-less expression is seen in a wider area, and this expression is thought to constitute the activating signal that determines the size of the spot. Last, the cells receiving the signal determine the colour they will take. The seasonal Bicyclus morphs appear to diverge at the later stages of signal activation and colour differentiation, and this also appears to be regulated by the hormone ecdysone. When ecdysone is present early in the young pupa, Distal-less expression is retained, and the hot/wet season form of the wing, with its large eyespot, is formed (Brakefield et al 1996; Koch et al 1996).

Here we see a critically important concept: The endocrine system mediates between the environment and gene expression. The nervous system senses the environmental change and activates hormones. The hormones then regulate gene expression. This type of neuroendocrine mediation of gene expression from the environment is seen in numerous species, and it has been a major part of the paradigm that H Fred Nijhout (see Nihjout 1999, 2003) has proposed for the environmental instruction of gene expression. Recent advances in insect neurophysiology have found the temperature sensing neuron channels, and they are expressed in the ecdysone-promoting regions of the insect CNS (P Garrity, personal communication).

\subsection{Direct environmental alterations of hormone production}

Such neuroendocrine control of phenotype has also been suggested for vertebrates and may be the basis for the temperature-sensitive sex determination schemes of turtles and crocodilians. When these embryos develop below a certain temperature, they are one sex; above that temperature, and they are the other sex. (The sex and setpoint differ between species, see Bull 1980). While the detailed mechanisms for this are not yet known, it appears to involve the enzyme aromatase. Unlike the situation in mammals, gonadal specification in reptiles and birds can be affected by hormones. Estrogen can organize the gonadal rudiment into ovaries. Aromatase can convert testosterone into estrogens. In some turtle species, aromatase is elevated at high temperatures and estrogen is made at the expense of testosterone. If estrogen synthesis is inhibited in turtle eggs by aromatase inhibitors male offspring are produced irrespective of temperature. This correlation is seen to hold under natural conditions as well. The aromatase activity of Emys is very low at the male-promoting temperature of $25^{\circ} \mathrm{C}$. At the female-promoting temperature of $30^{\circ} \mathrm{C}$, aromatase activity increases dramatically during the critical period for sex determination (Desvages et al 1993; Belaid et al 2001). Temperature-dependent aromatase activity is also seen in diamondback terrapins, and its inhibition masculinizes their gonads (Jeyasuria et al 1994).

However, sex appears truly to reside in the brain. Aromatase is produced in two major sites in the embryo - the gonads and the brain. The gonadal aromatase appears to be the same between the sexes. It's the brain aromatase activity that correlates with temperature and female sex. When Trachemys (red eared slider turtle) embryos were raised at high temperatures (to produce females), their brains had significantly higher aromatase activity than the brains of their siblings raised at lower, male-producing, temperatures (Willingham et al 2000). This increase in brain estrogen production may induce neuroendocrine changes that result in gonadal steroid formation and ovary determination.

When discussing environmental regulation of gene expression, it is important to keep in mind that gene activity does not necessarily mean gene transcription. The regulation of the gene product can occur at other points along the pathway to make a functional protein. One of the best-documented cases of temperature affecting protein activity and normal phenotype production is the temperature-sensitive tyrosinase found in Siamese cats, Himalayan cavies, mice, and guinea pigs (see Schmalhausen 1949). Some families of humans also have this condition, caused by a temperature-sensitive tyrosinase enzyme. Under normal (high) body temperatures, this enzyme is folded 
in a manner such that it becomes unstable and remains in the ER-Golgi apparatus to be degraded. However, at slightly lower temperatures - that of the ears, nose and extremities of the limb - the enzyme folds properly and is able to function (Berson et al 2000). King et al (1991) shown that the human 'Himalayan'-like condition is caused by the conversion of the CGG (Arg) at codon 422 to CAG (Gln). In the Himalayan mouse, the temperaturesensitive condition is caused by his420-to-arg mutation (Kwon et al 1989). Indeed, one can make black patches of fur anywhere on the body of a Himalayan rabbit by shaving the fur and placing an ice pack on its skin as it grows back (see Schmalhausen 1949).

\subsection{Epigenetic signals between organisms}

Signals that produce developmental changes act not only within the organism; they can also go from organism to organism. Interspecies epigenesis (Gilbert 2002) involves the developmental interactions between two species, such that signals from one species cause changes in the development of the other species. This interaction is often reciprocal, and it is the hallmark of developmental symbioses (see below). This reciprocal interaction means that niches can be constructed. As the environment changes the developing organism within it, the developing organism modifies the environment (Lewontin 1983; Odling-Smee et al 2003).

There is also the special epigenesis that occurs between the mammalian mother and the conceptus within her. These interactions involve placenta formation, the maintenance of the uterine environment through chorionic gonadotropin, and the suppression of the maternal immune response by modulators coming from the fetus and placenta. Recently, it was discovered that the fetus not only initiates placenta formation and the maintenance of pregnancy; it also signals the termination of pregnancy (Condon et al 2004). Here, the coordination between the maturation of the fetal lung and parturition is mediated by surfactant protein accumulating in the amnion. It appears that surfactant-A simulates IL- $1 \beta$ and NF- $\kappa B$ expression in the amniotic fluid macrophages and that these macrophages migrate into the uterus. NF- $\kappa \mathrm{B}$ is thought to increase the contractability of the uterine musculature through the activation of cyclooxygenase-2 (which stimulates the production of prostaglandins) and by antagonizing the progesterone receptor. Thus, the signal from within is transmitted by the immune system rather than by the neuroendocrine system.

\section{Signal transduction from environment to genome through induction}

One of the most interesting symbioses, from a medical point of view, is that between mammals and their gut microbes. Recent evidence shows that the gut bacteria actually regulate some of our intestinal genes. Moreover, this regulation is part of normal mammalian development, and these microbes are expected to be present if our gut is to be properly formed. The polymerase chain reaction (which is able to identify bacterial species that cannot be cultured) has revealed that bacteria have particular geographic distributions within us, such that the 400 bacterial species of the human colon are stratified into specific regions along the length and diameter of the gut tube. Here, they can attain densities of $10^{11}$ cells per milliliter (Savage 1977; Hooper et al 1998). Moreover, we have co-evolved to share our spaces with them, and we have even co-developed such that our cells are primed for their docking, and their prokaryotic cells are primed to induce gene expression from our nuclei (Bry et al 1996). We never lack these microbial components; we pick them up from the reproductive tract of our mother as soon as the amnion bursts. Xu and Gordon (2004) describe our microbiota as "a multifunctional organ whose component cell lineages provide metabolic traits that we have not fully evolved in our own genome." These traits include the ability to digest plant polysaccharides, the biotransformation of conjugated bile acids, the synthesis of vitamins $\mathrm{K}$ and $\mathrm{B} 12$, and the regulation of fat storage $(\mathrm{Xu}$ and Gordon 2004; Bäckhed et al 2004). Moreover, our symbiotic microbes also are involved with the differentiation of our gut and its associated immune system.

Bacteria are able to induce gene expression in mammalian intestines, and this gene expression is important for normal intestinal development. Umesaki (1984) noticed that a particular fucosyl transferase enzyme characteristic of mouse intestinal villi was induced by bacteria, and more recent studies (Hooper et al 1998) have shown that the intestines of germ-free mice can initiate, but not complete, their differentiation. To complete development, the microbial symbionts of the gut are needed. Microarray analysis of mouse intestinal cells (figure 2A; Hooper et al 2001) has shown that normally occurring bacteria can upregulate the transcription of several mouse genes, including those encoding colipase, which is important in nutrient absorption, angiogenin-3, which helps form blood vessels, and sprr2a, a small proline-rich protein that is thought to fortify matrices that underlie the intestinal epithelium. Stappenbeck et al (2002) have demonstrated that without particular intestinal microbes, the capillaries of the small intestinal villi fail to develop their complete vascular webs (figure $2 \mathrm{~B}, \mathrm{C}$ ).

As shown in figure 2, Bacteroides thetaiotaomicron appears to be critical for much of this induction of intestinal genes. Another set of bacteria-Bacteroides fragilis and Bacillus subtilis - appear to be needed together in order to induce the formation of the gut-associated lymphoid tissue (GALT). GALT mediates mucosal immunity and oral 
(A)

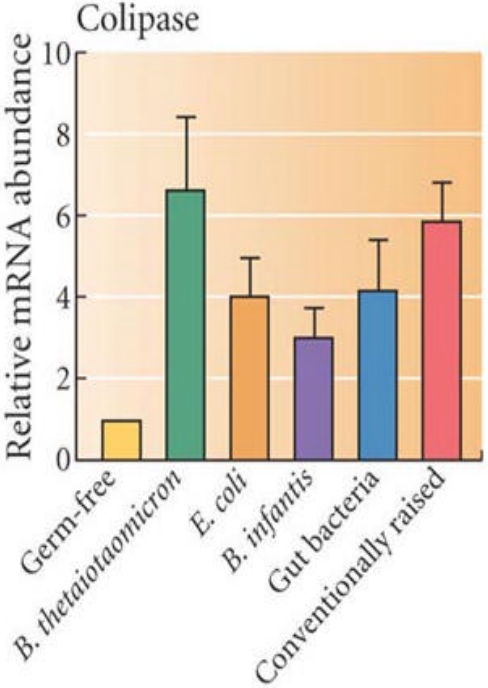

(B)

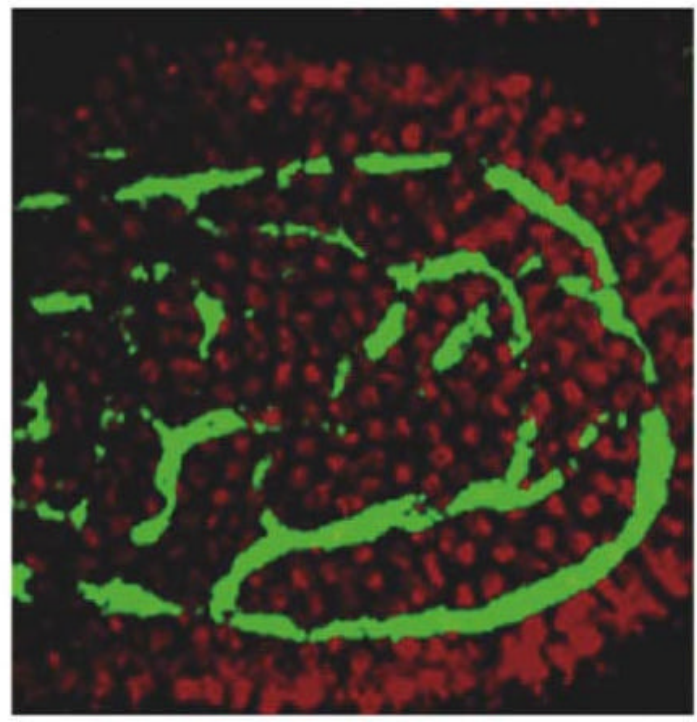

Angiogenin-3

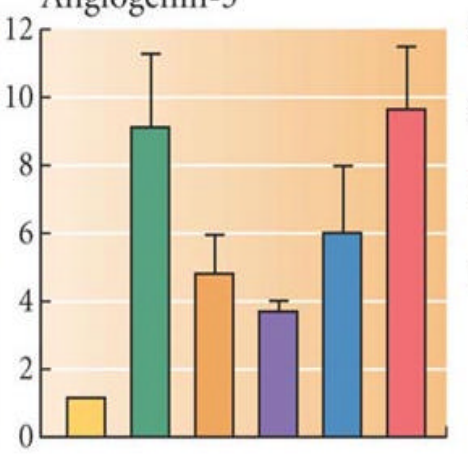

Sprr2a

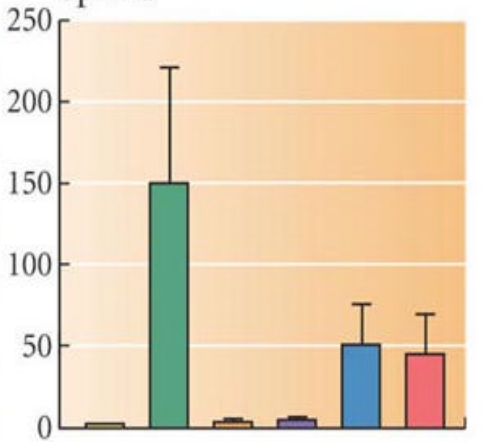

(C)

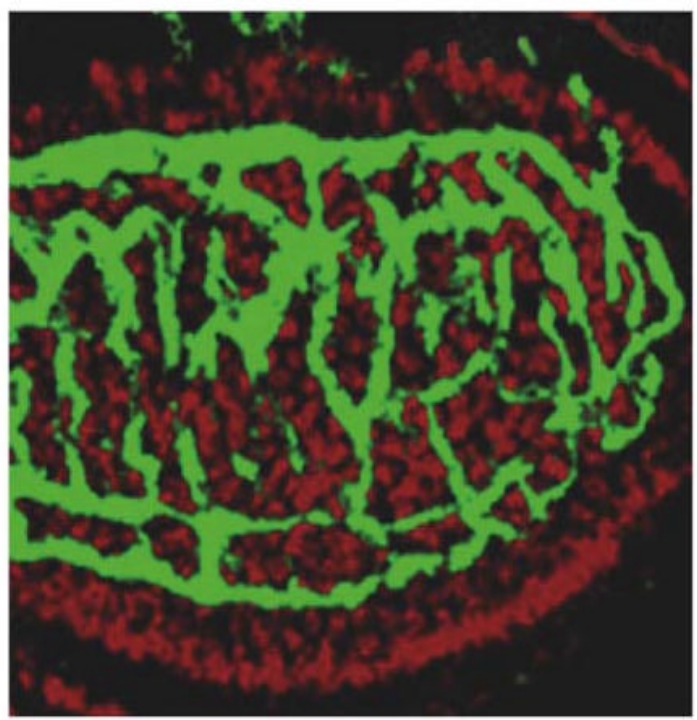

Figure 2. Specificity of host genome responses to different bacteria. (A) Mice raised in 'germ-free' environments were either left alone or inoculated with one or more types of bacteria. After ten days, the intestinal mRNAs were isolated and tested on microarrays. Mice grown in 'germ-free' conditions had very little expression of the genes encoding colipase, angiogenin-3, or sprr2a. Several different bacteria - Bacteroides thetaiotaomicron, E. coli, Bifidobacterium infantis, or an assortment of bacteria harvested from conventionally raised mice - can induce the genes for colipase and angionenin-3. B. thetaiotaomicron appears to be totally responsible for the 205-fold increase in sprr2a expression over that of germ-free animals. (B) Confocal microscope section of an intestinal villus capillary bed in a mouse raised 6 weeks in germ-free conditions. The capillaries are stained green. (C) Capillary network of an intestinal villus of a mouse raised 6-weeks in germ free conditions and then recolonized ten days with conventional gut microbes. The capillary network has fully developed. (A after Hooper et al 2001; B, C after Stappenbeck et al 2002; courtesy of J L Gordon.) 
immune tolerance, and its malfunction has been associated with allergies and with Crohn's disease (see Rook and Stanford 1998; Steidler 2001). Intestinal microbes have been shown to be needed for the maturation of the mouse gut-associated lymphoid tissue (Perey and Good 1968; Tlaskalova-Hogenovava and Stepanko 1980; Cebra 1999). When introduced into germ-free rabbit appendices, neither B. fragilis nor B. subtilis was capable of consistently inducing GALT or the mucosal B-cell repertoire. However, the combination of these bacteria consistently induced both (Rhee et al 2004). Since B. subtilis induced some response, it is possible that it is the major inducer, receiving help from $B$. fragilis. Moreover, when $B$. subtilis is mutated such that it lacked the ability to produce spores or the YqxM protein (both regulated by the SpoOA stress system) there was no induction of the GALT (Rhee et al 2004).

Interestingly, microarray analysis comparing gene expression in the digestive tracts of germ-free and conventionally raised zebrafish show the same induction of gene expression by the microbes. There are at least 200 microbially induced genes in the gut of the fish, including several that are involved in epithelial proliferation, nutrient metabolism, and immune responsiveness (Rawls et al 2004).

Therefore, mammals have co-evolved with bacteria such that our bodily phenotypes do not develop properly without them. Moreover, just as differentiating cells provide different development functions in the body, so do the different species of bacteria. Our distinction between inside and outside, between ecology and development may have to be altered (see Gilbert 2002), and Paul Weiss' description of the developing body as an ecosystem of interacting genes, cells, tissues, and environments seems very appropriate.

\section{Environmental signals regulating DNA modification}

A recent study by Waterland and Jertle (2003a) has shown that dietary alterations can produce changes in DNA methylation, and that these methylation changes can affect the phenotype. They showed this by using mice containing the viable yellow allele of Agouti. Agouti is a dominant gene that gives mice yellowish hair colour. The viable yellow allele contains a transposable element inserted into the first exon of this gene. This is not a totally unusual situation, transposons represent about $35 \%$ of the human genome, and about $4 \%$ of our genes have transposable elements inserted in them (see Waterland and Jirtle 2003a). These transposon insertion sites are very interesting for regulation: whereas most regions of the adult genome have hardly any intraspecies variation in
CpG methylation, there are large DNA methylation differences between individuals at the sites of transposon insertion. Such $\mathrm{CpG}$ methylation can block gene transcription.

Waterland and Jirtle fed pregnant viable yellow mice methyl donor supplements - folate, choline, betain, and looked at the phenotype of their offspring. They found that the more methyl supplementation, the greater the methylation of the transposon insertion site, and the darker the mouse's pigmentation. Figure 3 shows the phenotype of the mice born from mothers given different amounts of methyl donors during their pregnancy. These methylation differences were seen throughout the body.

Waterland and Jirtle (2004) also provide evidence that DNA methylation might be the critical link by which nutritional deficiencies during early pregnancy might cause chronic diseases in the adult. Epidemiological data (reviewed in Jablonka and Lamb 2002; Waterland and Jirtle 2004) have indicated that prenatal nutrition influences adult susceptibility to cardiovascular disease, obesity, cancers, and type 2 diabetes. Evidence from studies of early development in vitro in both humans and mice (Doherty et al 2000; Khosla et al 2001; Cox et al 2002; DeBaun et al 2003) has revealed that culture media conditions can alter the methylation of several genes that normally show specific paternal or maternal imprinting. Moreover, a recent abstract (Waterland and Jirtle 2003b; quoted in Waterman and Jirtle 2004) concludes that if newly weaned mice were given a diet transiently deficient in methyl donors, the insulin-like growth factor-2 (IGF2) genes failed to remain properly imprinted. Moreover, this imprinting failure continued for months after the mice were restored to a full diet. Recent studies have also shown that environmentally induced methylation changes in newborn rats can profoundly alter adult behaviours (by altering the transcription of the glucocorticoid receptor in the brain; Weaver et al 2004). The supplementation of pregnant women's diets with methyl donors (particularly folate) in order to prevent neural tube defects has been one of the major success stories in preventative medicine (Wilson et al 2003). This methylation may be having several effects on phenotype.

Developmental biology is rejoining the real world. Moreover, it is forming important interdisciplinary alliances with ecology and physiology to supplement its existing ties to cell biology and genetics. In the $1800 \mathrm{~s}$, embryology had been the unifying area of biology that tied together the studies of cytology, evolution, heredity, ecology, and physiology. The research in ecological developmental biology shows that the developing body is instructed not only by the inherited genome but also by the microbes and diet it encounters. Moreover, these are not accidental encounters. Our development has evolved to expect these signals from the environment and is in- 


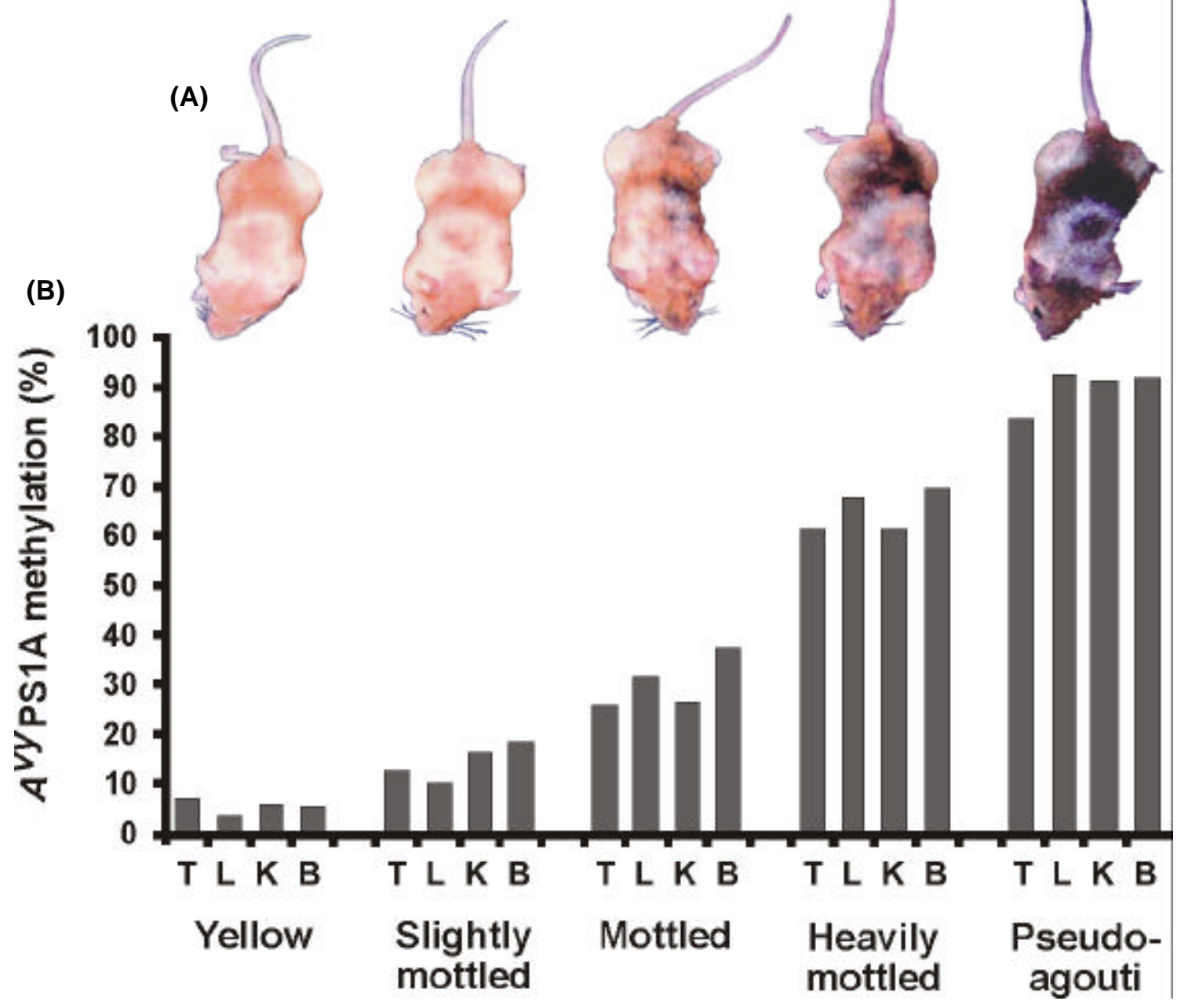

Figure 3. Dependency of phenotype on DNA methylation at the viable Agouti locus. (A) The same genotype, but with different phenotypes due to methyl donors in the maternal diet. Isogenic $A^{v y} / a$ animals experienced different dietary methyl supplementation during development. In the yellow mice, the viable Agouti gene was active. The increasing amount of brown pigment correlates with the inactivation of the viable Agouti gene due to methylation of its DNA. (B) Average percent methylation of seven CpG sites in the $A^{v y}$ PS1A site in tail (T), liver (L), kidney (K), and brain. (From Waterland and Jirtle 2003a. Photograph courtesy of the authors.)

complete without it. If it takes a village to raise a child, it takes an ecosystem to raise an embryo.

\section{Acknowledgements}

Funding for this work was through NSF grant IBN0316025. I wish to gratefully acknowledge the helpful discussions of the ecology, physiology, microbiology, and marine biology faculty at Swarthmore College. I wish to thank Dr R Tuan and Dr V Nanjundiah for allowing me to publish similar reviews in their respective journals.

\section{References}

Adams M B 1980 Severtsov and Schmalhausen: Russian morphology and the evolutionary synthesis; in The evolutionary synthesis (eds) E Mayr and W B Provine (Cambridge: Harvard University Press) pp 193-225

Aitken R J, Koopman P and Lewis S E M 2004 Seeds of concern; Nature (London) 432 48-52

Bäckhed F, Ding H, Wang T, Hooper L V, Koh G Y, Nagy A, Semenkovitch C F and Gordon J I 2004 The gut microbiota as an environmental factor that regulates fat storage; Proc. Natl. Acad. Sci. USA 101 15718-15723

Belaid B, Richard-Mercier N, Pieau C and Dorizzi M 2001 Sex reversal and aromatase in the European pond turtle: treatment with letrozol after thermosensitive period for sex determination; J. Exp. Zool. 290 490-497

Berson J F, Frank D W, Calvo P A, Bieler B M and Marks M S 2000 A common temperature-sensitive allelic form of human tyrosinase is retained in the endoplasmic reticulum at the nonpermissive temperature; J. Biol. Chem. 275 12281-12289

Bolker J A 1995 Model systems in developmental biology; BioEssays 17 451-455 
Brakefield P M and Reitsma N 1991 Phenotypic plasticity, seasonal climate, and the population biology of Bicyclus butterflies (Satyridae) in Malawi; Ecol. Entomol. 16 291303

Brakefield P M, Gates J, Keys D, Kesbeke F, Wijngaarden P J, Montelro A, French V and Caroll S B 1996 Development, plasticity, and evolution of butterfly eyespot patterns; Nature (London) 384 236-242

Bry L, Falk P G, Midtvedt T and Gordon J I 1996 A model of host-microbial interactions in an open mammalian ecosystem; Science 273 1380-1383

Bull J J 1980 Sex determination in reptiles; Q. Rev. Biol. 55 3-21

Cebra J J 1999 Influences of microbiota on intestinal immune system development; Am. J. Clin. Nutr. (Suppl.) 69 1046S$1051 \mathrm{~S}$

Condon J C, Jeyasuria P, Faust J M and Mendelson C R 2004 Surfactant protein secreted by the maturing mouse fetal lung acts as a hormone that signals the initiation of parturition; Proc. Natl. Acad. Sci. USA 101 4978-4983

Cox G F, Burger J, Lip V, Mau U A, Sperling K, Wu B L and Horsthemke B 2002 Intracytoplasmic sperm injection may increase the risk of imprinting defects; Am. J. Hum. Genet. 71 162-164

DeBaun M R, Niemitz E L and Feinberg A P 2003 Association of in vitro fertilization with Beckwith-Wiedemann syndrome and epigenetic alterations of LITI and H19; Am. J. Hum. Genet. 72 156-160

Desvages G, Girondot M and Pieau C 1993 Sensitive stages for the effects of temperature on gonadal aromatase activity in embryos of the marine turtle; Dermochelys coriacea; Gen. Comp. Endocrinol. 92 54-61

Doherty A S, Mann M R, Tremblay K D, Bartolomei M S and Schultz R M 2000 Differential effects of culture on imprinted H19 expression in the preimplantation mouse embryo; Biol. Reprod. 62 1526-1535

Gilbert S F 1996 Enzyme adaptation and the entrance of molecular biology into embryology; in The philosophy and history of molecular biology New perspectives (ed.) S Sarkar (Dordrecht: Kluwer Academic Publishers) pp 101-123

Gilbert S F 2001 Ecological developmental biology: Developmental biology meets the real world; Dev. Biol. 233 1-12

Gilbert S F 2002 The genome in its ecological context: Philosophical perspectives on interspecies epigenesis; Ann. N.Y. Acad. Sci. 981 202-218

Gilbert S F and Bolker J 2003 Ecological developmental biology: Preface to the symposium; Evol. Dev. 5 3-8

Gould S J 1977 Ontogeny and phylogeny (Cambridge: Harvard University Press)

Hertwig O 1894 Zeit- und Streitfragen der Biologie I. Präformation oder Epigenese? Grundzüge einer Entwicklungstheorie der Organismen. Gustav Fischer Jena. Translated as The biological problem of to-day: Preformation or epigenesis? (P C Mitchell transl.) (New York: Macmillan)

Hooper L V, Bry L, Falk P G and Gordon J I 1998 Hostmicrobial symbiosis in the mammalian intestine: exploring an internal ecosystem; BioEssays 20 336-343

Hooper L V, Wong M H, Thelin A, Hansson L, Falk P G and Gordon J I 2001 Molecular analysis of commensal hostmicrobial relationships in the intestine; Science 291 881-884

Jablonka E and Lamb M J 2002 The changing concept of epigenetics; Ann. N.Y. Acad. Sci. 981 82-96

Jeyasuria P, Roosenburg W M and Place A R 1994 Role of P450 aromatase in sex determination of the diamondback terrapin; Malaclemys terrapin; J. Exp. Zool. 270 95-111
Khosla S, Dean W, Brown D, Reik W and Feil R 2001 Culture of preimplantation mouse embryos affects fetal development and the expression of imprinted genes; Biol. Reprod. 64918 926

King R A, Townsend D, Oetting W, Summers C G, Olds D P, White J G and Spritz R A 1991 Temperature-sensitive tyrosinase associated with peripheral pigmentation in oculocutaneous albinism; J. Clin. Invest. 87 1046-1053

Koch P B and Buchmann D 1987 Hormonal control of seasonal morphs by the timing of ecdysteroid release in Araschnia levana (Nymphalidae: Lepidoptera); J. Insect Physiol. 36 $159-164$

Koch P B, Brakefield P M and Kesbeke F 1996 Ecdysteroids control eyespot size and wing colour pattern in the polyphenic butterfly Bicyclus anynana (Lepidoptera Satyridae); J. Insect. Physiol. 42 223-230

Kwon B S, Halaban R and Chintamaneni C 1989 Molecular basis of mouse Himalayan mutation; Biochem. Biophys. Res. Commun. $161252-260$

Levit G S, Hossfeld U and Olsson L 2004 The integration of Darwinism and evolutionary morphology: Alexej Nikolajevich Sewertzoff (1866-1936) and the developmental basis of evolutionary change; J. Exp. Zool. B 302 343-354

Lewontin R C 1983 Gene, organism and environment; in Evolution from molecules to men (ed.) D S Bendall (Cambridge: Cambridge University Press) pp 273-285

Lewontin R 2000 The triple helix: Gene organism and environment (Cambridge: Harvard University Press)

Lewontin R and Levins R 1976 The problem of Lysenkoism; in The radicalisation of science (eds) $\mathrm{H}$ Rose and S Rose (London: Macmillan) pp 32-65

Lindegren C C 1966 The cold war in biology (Ann Arbor: Planarian Press)

McFall-Ngai M J 2002 Unseen forces: the influence of bacteria on animal development; Dev. Biol. 242 1-14

Nijhout H F 1991 The development and evolution of butterfly wing patterns (Washington DC: Smithsonian Institution Press)

Nijhout H F 1999 Control mechanisms of polyphonic development in insects; BioScience 49 181-192

Nijhout H F 2003 Development and evolution of adaptive polyphenisms; Evo. Dev. 5 9-18

Nyhart L K 1995 Biology takes form: Animal morphology and the German Universities 1800-1900 (Chicago: University of Chicago Press)

Odling-Smee F J, Laland K N and Feldman M S 2003 Niche construction The neglected process in evolution (Princeton: Princeton University Press)

Perry D and Good R 1968 Experimental arrest and induction of lymphoid development in lymphoepithelial tissues of rabbits; Lab. Invest. 18 15-26

Rawls J F, Samuel B F and Gordon J I 2004 Gnotobiotic zebrafish reveal evolutionarily conserved responses to the gut microbiota; Proc. Natl. Acad. Sci. USA 101 4596-4601

Rhee K-J, Sethupathi P, Driks A, Lanning D K and Knight K L 2004 Role of commensal bacteria in development of gutassociated lymphoid tissues and preimmune antibody repertoire; J. Immunol. 172 1118-1124

Rook G A and Stanford J L 1998 Give us this day our daily germs; Immunol. Today 19 113-116

Sapp J 1987 Beyond the gene (New York: Oxford University Press)

Savage D C 1977 Microbial ecology of the gastrointestinal tract; Annu. Rev. Micorobiol. 31 107-133

Schmalhausen I I 1949 Factors of evolution: The theory of stabilizing selection (Chicago: University of Chicago Press) 
Stappenbeck T S, Hooper L V and Gordon J I 2002 Developmental regulation of intestinal angiogenesis by indigenous microbes via Paneth cells; Proc. Natl. Acad. Sci. USA 99 15451-15455

Steidler L 2001 Microbiological and immunological strategies for treatment of inflammatory bowel disease; Microbes Infect. 3 $1157-1166$

Sultan S E 2003 Phenotypic plasticity in plants: a case study in ecological development; Evo. Dev. 5 25-33

Tlaskalova-Hogenovava H and Stepankova R 1980 Development of antibody formation in germ-free and conventionally reared rabbits the role of intestinal lymphoid tissue in antibody formation to E. coli antigens; Folia Biol. 2681

Umesaki Y 1984 Immunohistochemical and biochemical demonstration of the change in glycolipid composition of the intestinal epithelial cell surface in mice in relation to epithelial cell differentiation and bacterial association; J. Histochem. Cytochem. 32 299-304

van der Weele C 1999 Images of development: Environmental causes in ontogeny (Albany: SUNY Press)

Waddington C H 1953 Genetic assimilation of an acquired character; Evolution 7 118-126

Waterland R A and Jirtle R L 2003a Transposable elements: Tragets for early nutritional effects of epigenetic gene regulation; Mol. Cell. Biol. 23 5293-5300
Waterland R A and Jirtle R L 2003b Developmental relaxation of insulin-like growth factor 2 imprinting in the kidney is determined by weanling diet; Pediat. Res. (Suppl.) 53 5A

Waterland R A and Jirtle R L 2004 Early nutrition, epigenetic changes at transposons and imprinted genes, and enhanced susceptibility to adult chronic diseases; Nutrition 20 63-68

Weaver I C, Cervoni N, Champagne F A, D-Alessio A C, Sharma S, Seckl J R, Dymov S, Szyf M and Meaney M J 2004 Epigenetic programming by maternal behavior; Nature Neurosci. 7 847-854

Weismann A 1875 "Über den Saison-Dimorphismus der Schmetterlinge; in Studien zur Descendenz-Theorie (Leipzig: Engelmann)

West-Eberhard M J 2004 Developmental plasticity and evolution (New York: Oxford University Press)

Willingham E, Baldwin R, Skipper J K and Crews D 2000 Aromatase activity during embryogenesis in the brain and adrenalkidney-gonad of the red-eared slider turtle; a species with temperature-dependent sex determination; Gen. Comp. Endocrinol. 119 202-207

Wilson R D et al 2003 The use of folic acid for the prevention of neural tube defects and other congenital anomalies; J. Obstet. Gynaecol. Can. 25 959-973

$\mathrm{Xu} \mathrm{J}$ and Gordon J I 2004 Honor thy symbionts; Proc. Natl. Acad. Sci. USA 100 10452-10459

ePublication: 7 January 2005 